\title{
Medverkande författare
}

CHRISTIAN ANDERSSON är sociolog och disputerade 1985 på avhandlingen Peasant or Proletarian? Wage Labour and Peasant Economy during Industrialization. The Algerian Experience. Andersson har också varit Afrikahandläggare på UD, nyhetsreporter på Sveriges Radio, chef för Europaparlamentets informationskontor och lektor i journalistik.

PAULINA DE LOS REYES är professor i ekonomisk historia och verksam vid Stockholms universitet. Hon var initiativtagare till Husbyprojektet och (med)författare till flera publikationer om Husbyhändelserna. Hennes forskningsområde rör intersektionella maktanalyser och historisk förändring.

ANTONIO GRAMSCI är en av den västerländska marxismens stora tänkare. Han föddes i Italien I89I och dog i förtid 1937 efter att ha spenderat ett decennium i fängelse under den fascistiska regimen. Under sin tid i fängsligt förvar sysselsatte han sig med att skriva den stora mängd anteckningar som blivit kända som hans mest betydelsefulla verk, Quaderni del carcere, "Anteckningsböcker från fängelset”. I svensk översättning finns sedan tidigare ett urval "fängelseanteckningar" i boken En kollektiv intellektuell (1967) och i tidskriften Fronesis nr I (1998). En del av Gramscis många brev från tiden i fångenskap finns på svenska i samlingen Brev från fängelset (senast utgiven 2007).

MARCUS LAURI är filosofie doktor i statsvetenskap och lektor i socialt arbete vid Mittuniversitetet i Östersund. Lauri ingår i den grupp forskare vid Stockholms universitet som samlade berättelser från boende 
under oroligheterna i Husby 20I3, i syfte att lyfta fram deras perspektiv på händelserna. Han forskar också om nyliberalismens effekter på svensk välfärd.

во ROTHSTEIN är professor emeritus i statsvetenskap vid Göteborgs universitet och numera även medaljbehängd av självaste H.M. Konungen för sina betydande insatser inom det statsvetenskapliga forskningsområdet. Bland hans många publikationer kan särskilt nämnas de tre inflytelserika svenska arbetena om den moderna staten: Den socialdemokratiska staten (2 uppl. 2010), Den korporativa staten (1992) och Vad bör staten göra? (3 uppl. 2010).

ANDERS STEPHANSON är professor i amerikansk historia vid Columbia University i New York. Hans forskning är inriktad på USA:s internationella relationer, framför allt det kalla kriget. Bland hans publicerade verk kan nämnas Kennan and the Art of Foreign Policy (1989) och Manifest Destiny. American Expansionism and the Empire of Right (1995). En samling essäer om det kalla kriget och dess periodisering kommer ut på Verso när det blir dags.

MIKAEL STIGENDAL är professor i sociologi vid Malmö universitet. Frågan om hur samhället hänger ihop har i alla år varit hans huvudintresse och för att söka svar på den har han bedrivit mycket forskning om städer. Hans senaste bok är Sambällsorientering - för en hållbar integration (202I), författad tillsammans med Erik Amnå.

KLAS ÅMARK är professor emeritus i historia vid Stockholms universitet. Han har bland annat forskat om den svenska arbetsmarknaden och välfärdsstaten, om Sveriges relation till Nazityskland och om Förintelsen. Bland hans många böcker kan nämnas Hundra år av välfärdspolitik. Välfärdsstatens framväxt i Norge och Sverige (2005), Att bo granne med ondskan. Sveriges förhällande till nazismen, Nazityskland och Förintelsen (201I) och hans senaste bok, Främlingar på tåg. Sverige och Förintelsen (202I). 


\section{Recensenter}

ANDERS BJÖRNSSON är publicist och historiker och har översatt tysk klassisk skönlitteratur till svenska.

JONNY HJELM är professor i historia vid Umeå universitet.

SARAH SCHULMAN är doktorand i statsvetenskap vid Lunds universitet och styrelsemedlem i Jiddischsällskapet i Stockholm. 

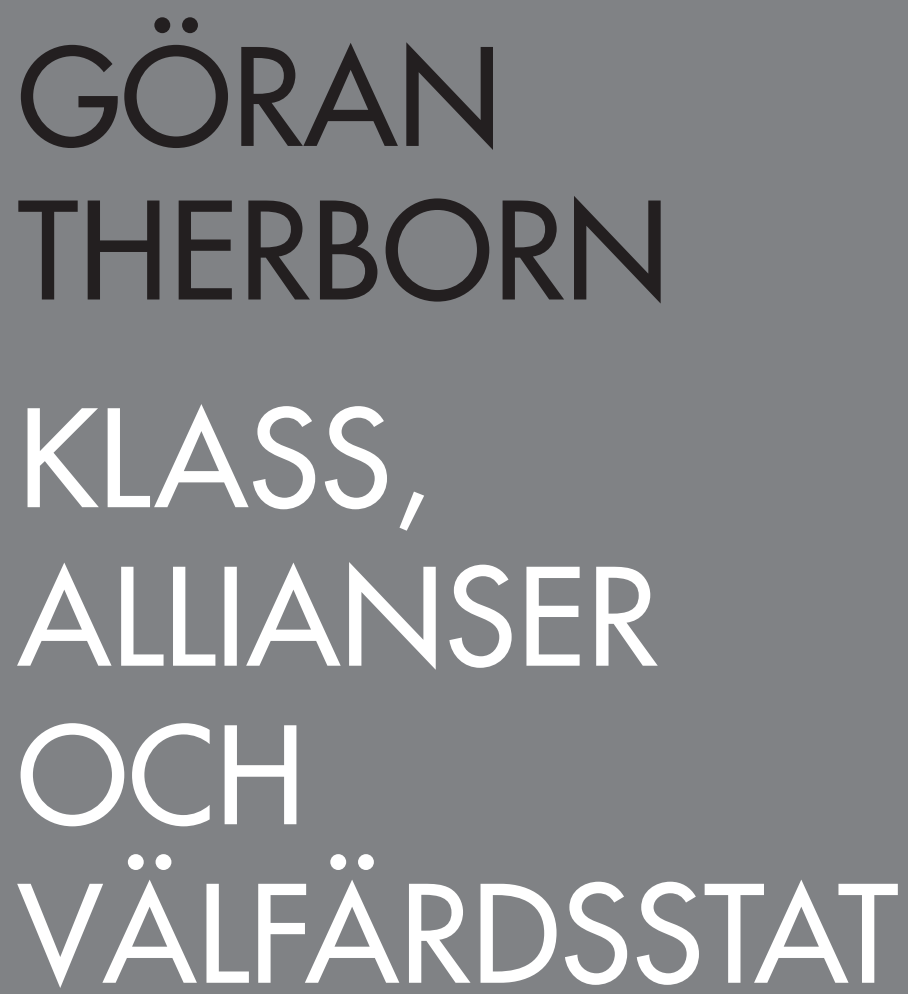

Analys och teori i arbete 1967-2021

Boken innehåller artiklar från tidskrifter som New Left Review, Zenit och Arkiv samt kapitel ur böcker som sedan länge är utgångna hos sina respektive förläggare.

Arkiv förlag, 418 sidor

»Läs mer om boken på www.arkiv.nu« 